Article

\title{
New Gastropod Vectors and Tetrodotoxin Potential Expansion in Temperate Waters of the Atlantic Ocean
}

\section{Marisa Silva ${ }^{1,2}$, Joana Azevedo ${ }^{1,3}$, Paula Rodriguez ${ }^{4}$, Amparo Alfonso ${ }^{4}$, Luis M. Botana ${ }^{4}$ and Vítor Vasconcelos $1,2, *$}

1 Department of Biology, Faculty of Sciences, University of Porto, Rua do Campo Alegre, 4619-007 Porto, Portugal; E-Mails: marisasilva17@gmail.com (M.S.); joana_passo@hotmail.com (J.A.)

2 Center of Marine and Environmental Research-CIMAR/CIIMAR, University of Porto, Rua dos Bragas, 289, 4050-123 Porto, Portugal

3 Department of Chemical and Biomolecular Sciences, School of Health and Technology of Porto, Vila Nova de Gaia, 4400-330 Vila Nova de Gaia, Portugal

4 Department of Pharmacology, Faculty of Veterinary, University of Santiago of Compostela, 27002 Lugo, Spain; E-Mails: paula.rodriguez17@ rai.usc.es (P.R.); amparo.alfonso@usc.es (A.A.); Luis.Botana@usc.es (L.M.B.)

* Author to whom correspondence should be addressed; E-Mail: vmvascon@ fc.up.pt; Tel.: +351-223401814; Fax: +351-223390608.

Received: 31 January 2012; in revised form: 16 March 2012 / Accepted: 17 March 2012 / Published: 26 March 2012

\begin{abstract}
Tetrodotoxin is a potent low weight marine toxin found in warm waters, especially of the Indian and Pacific Oceans. Intoxications are usually linked to the consumption of the puffer fish, although TTX was already detected in several different edible taxa. Benthic organisms such as mollusks and echinoderms, with different feeding habits, were collected monthly along the Portuguese coast from the summer of 2009 until the end of 2010. The extraction and analysis techniques were optimized and TTX and some analogues were detected for the first time in two intertidal gastropod species-Gibbula umbilicalis and Monodonta lineata by LC-MS/MS and UPLC-MS/MS. Although the levels are low, these findings suggest that monitoring of TTX and analogues in North Atlantic species should be implemented so as to detect potentially new toxin vectors and seasonal and/or geographical patterns.
\end{abstract}


Keywords: tetrodotoxin; new vectors; gastropods; North Atlantic Waters

\section{Introduction}

Tetrodotoxin (TTX) is a low weight potent neurotoxin, named after the Tetradontidae fish family from where it was first isolated in 1909 by Tahara and Hirata [1]. TTX is an interesting toxin, since it was reported in several taxa genetically not close related; from bacteria; marine invertebrates; terrestrial and marine vertebrates [2]. Neither its biochemical path nor its true origin is fully clarified, since three hypotheses point to its origin: endogenous [3,4], through food-chain [5-8] or through symbionts [9-12].

TTX is an extremely potent toxin, it binds specifically to site 1 of the voltage-gated sodium channels (Nav), occluding the external pore blocking the cellular communication and causing death by cardio-respiratory paralysis [13-16]. Several poisoning incidents have occurred, especially in Asia, with Japan being the most affected country and where Fugu is considered a delicacy. Japan is the only country to have guideline values for TTX [17]. Although TTX-bearers are typical of warm waters, recent studies report the possible migration of these toxic species from the Red Sea to the Mediterranean Sea through the Suez Canal [18-20]. This may happen due the opening of new corridors allied to the increase of water temperature as a result of climate change. These factors all together probably influenced the bidirectional migration of species between the Red Sea and the Mediterranean Sea, resulting in the increase of poisoning incidents, especially due to the ingestion of toxic alien species, among them TTX-bearers [18-22]. A good example of intoxication incidents caused by TTX-bearers was the ingestion of the elongated puffer, Lagocephalus sceleratus. Its presence in the Mediterranean was first reported in 2003, causing several poisoning incidents in Egypt in the end of 2004 and in Israel between 2005 and 2008. Fortunately all patients recovered [18,20,23].

In October 2007 a case of TTX poisoning occurred in Malaga, Spain, due to the ingestion of a specimen of Charonia lampas, an autochthonous predatory gastropod from Atlantic and Mediterranean waters, caught in the southern Portuguese waters [21]. This episode was the first report TTX occurrence in autochthonous species in Atlantic and Mediterranean waters and triggered our investigation to monitor different invertebrate species in several sites of our coast [21].

In this work our goal was to detect the presence of TTX and some analogues in several marine invertebrate species collected along the continental Portuguese coast, by using UPLC-MS/MS and LC-MS/MS.

\section{Results and Discussion}

In this study, 134 samples were collected in a monthly sampling program, from July 2009 until November 2010, in 13 sites distributed along the Portuguese coast (Figure 1). The collected species belonged to different taxa and included gastropods (Monodonta lineata, Monodonta turbinata, Gibbula umbilicalis, Gibbula magus, Littorina littorea, Littorina saxatilis, Nucella lapillus, Ocenebra erinacea, Calliostoma zizyphinum, Patella intermedia, Charonia lampas), bivalves (Mytilus galloprovincialis), sea-urchins (Paracentrotus lividus) and sea-stars (Marthasterias glacialis). The naturally contaminated 
Charonia lampas and Lagocephalus sceleratus, obtained in former works [21,24], were used as standards in the LC-MS/MS analysis and provided us with the retention times of TTX and of the other analogues as follows; TTX (21.14 $\mathrm{min})$, 4-epiTTX (20.4 $\mathrm{min})$, 5,6,11-trideoxyTTX (13.7-14.2 $\mathrm{min})$, monodeoxyTTX (18.08-18.80 $\mathrm{min}), 11$-norTTX-6-ol (19.0-19.7 $\mathrm{min})$ and 4-anhydroTTX (18.9 $\mathrm{min})$ (Figure 2).

Figure 1. Location of the sampling points in the North Atlantic Portuguese coast: 1 Viana do Castelo; 2 Esposende; 3 Póvoa do Varzim; 4 Angeiras; 5 Memória; 6 Valadares; 7 Aguda; 8 São Martinho do Porto; 9 São Torpes; 10 Porto Côvo; 11 Monte Clérigos; 12 Vila Nova de Milfontes; 13 Almograve.

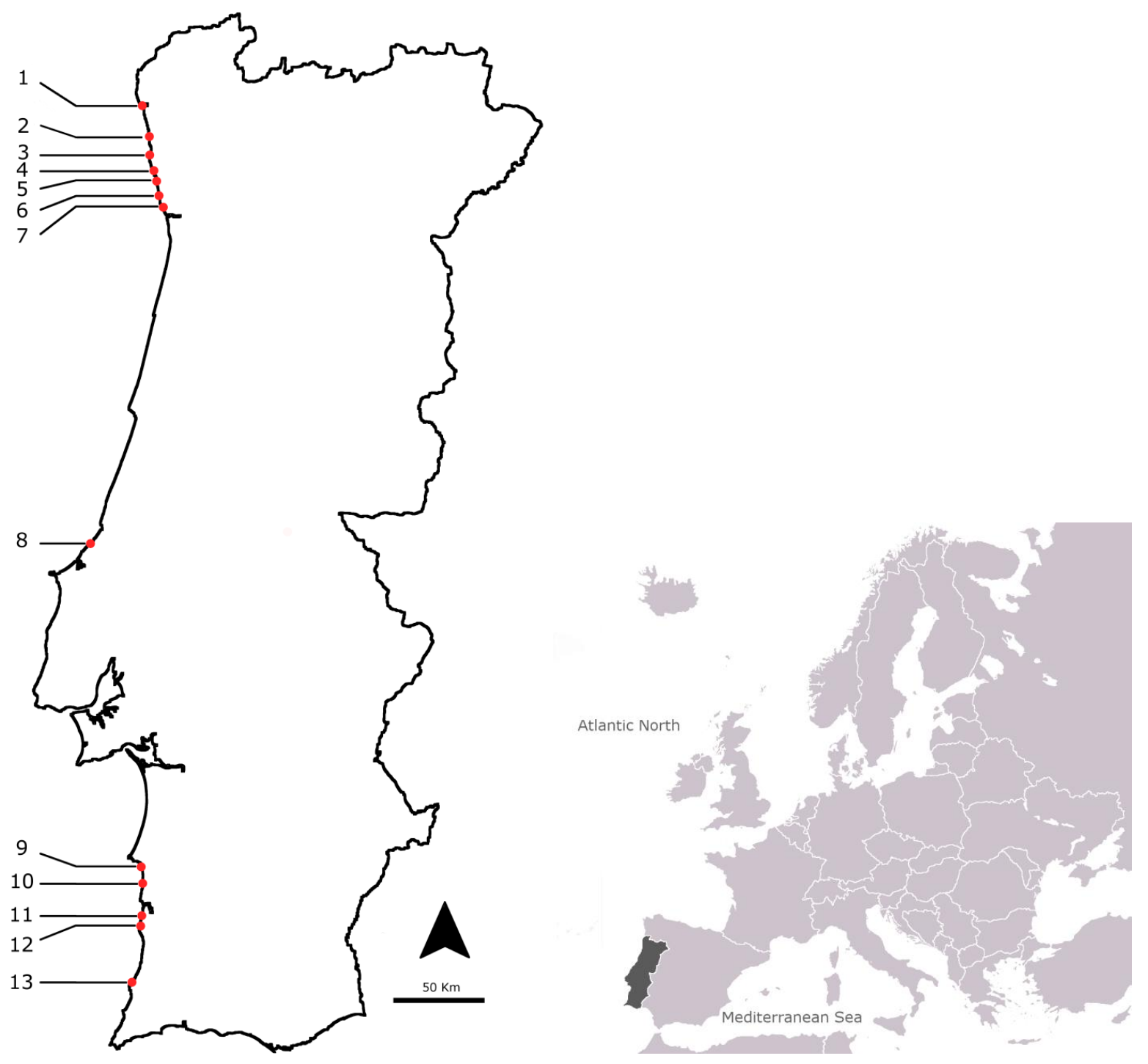


Figure 2. Mass chromatograms of the LC-ESI-CID-MS/MS obtained under MRM operation of the TTX standard and naturally-contaminated samples of Charonia lampas and Lagocephalus sceleratus. (A) MRM of TTX standard (1500 ng/mL), m/z $320>302$; (B) Extracted Ion Chromatogram (XIC) of a naturally-contaminated sample of C. lampas with TTX and the analogues 4-epiTTX; 5,6,11-trideoxyTTX; monodeoxyTTX; 4,9-anhydroTTX; (C) XIC of a naturally-contaminated sample of L. sceleratus with the analogues 11-norTTX-6-ol $\mathrm{m} / \mathrm{z}, 290>272$.

(A)

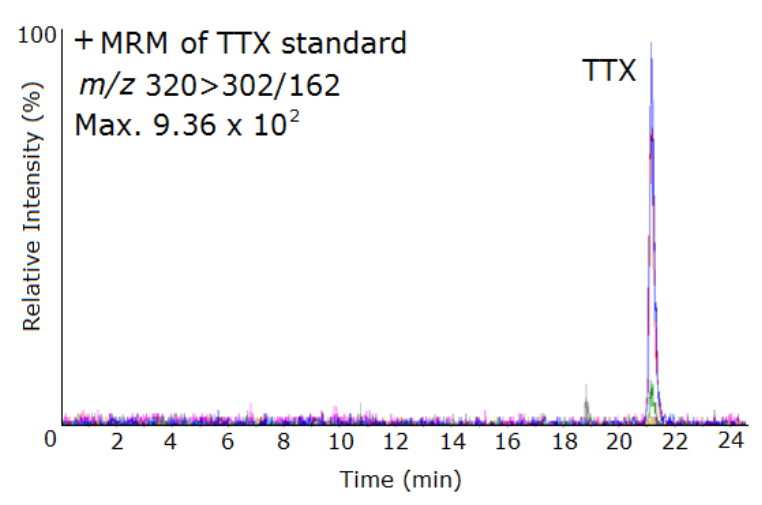

(C)

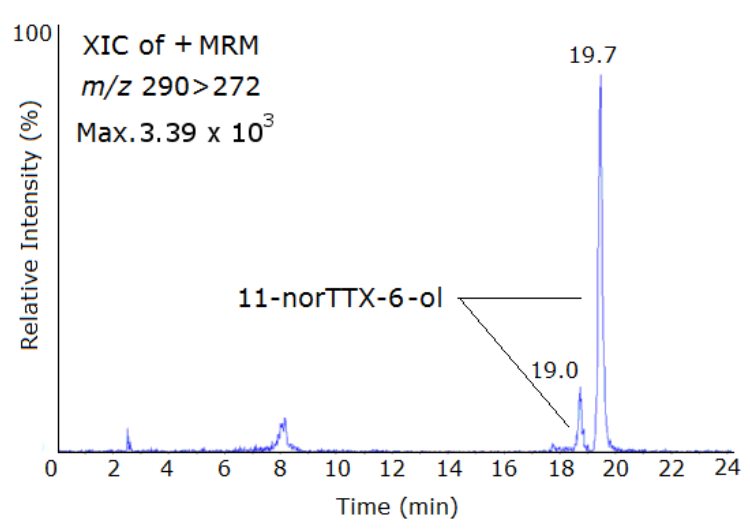

(B)

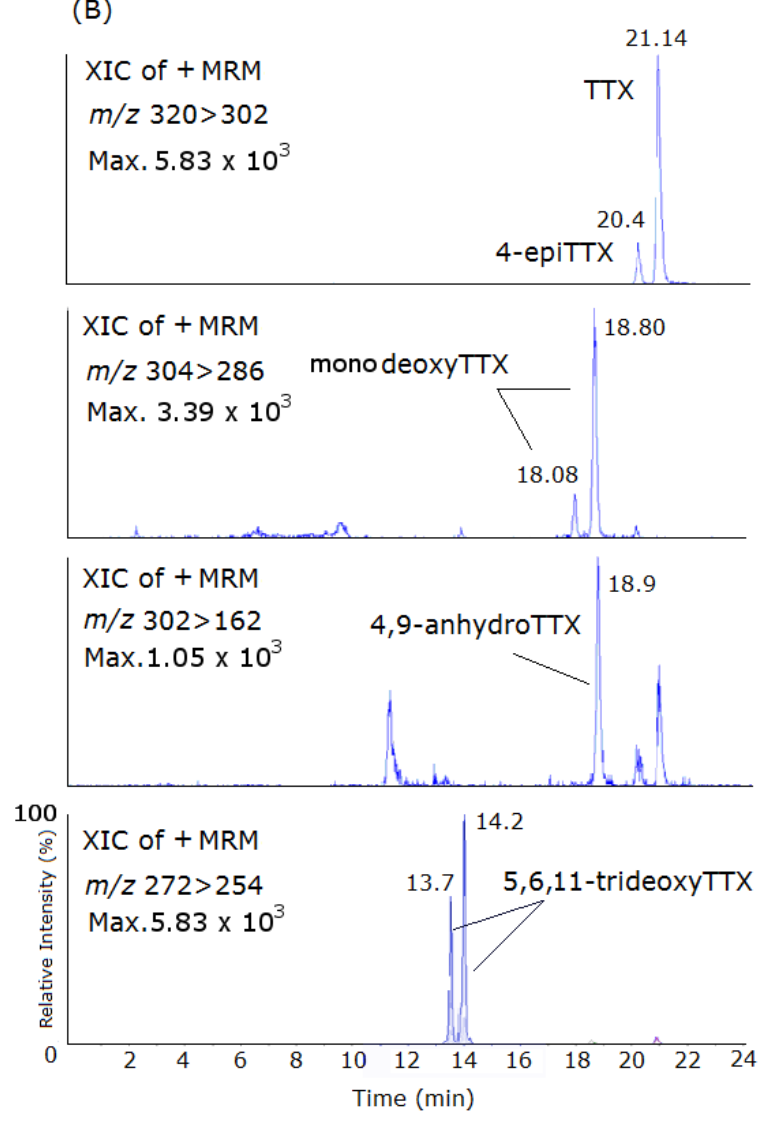

Five protonated molecules $[\mathrm{M}+\mathrm{H}]^{+}$at $\mathrm{m} / \mathrm{z} 320,302,304,290$ and 272 corresponding to TTX plus its derivatives were detected. The MRM transitions selected were: TTX and 4-epiTTX: $320>302 / 162$; 4,9-anhydroTTX: 302 > 256/162; monodeoxyTTX: 304 > 286/176; 11-norTTX-6-ol: $290>$ 272/162 and 5,6,11-trideoxyTTX: $272>254 / 162$. Quantification was done with the most abundant ion in the fragment spectra: 302 (TTX and 4-epiTTX), 162 (4,9-anhydroTTX), 286 (monodeoxyTTX), 272 (11-norTTX-6-ol) and 254 (5,6,11-trideoxyTTX) (Figure 2).

The limits of detection and quantification (LOD/LOQ) of the LC-ESI-CID-MS/MS for TTX were $16 \mathrm{ng} / \mathrm{mL}(\mathrm{S} / \mathrm{N}>3)$ and $63 \mathrm{ng} / \mathrm{mL}(\mathrm{S} / \mathrm{N}>10)$, respectively.

For the UPLC-MS/MS the LOD (S/N > 3) was $1.7 \mathrm{ng} / \mathrm{mL}$, and the LOQ (S/N > 10) was $5 \mathrm{ng} / \mathrm{mL}$. TTX and analogue contents were identified and calculated against TTX standard (Figure 3), presuming that the toxin and its derivatives had the same molar response factor in each apparatus. A sample was considered positive when the toxin levels detected were above the LOQ. 
Figure 3. Mass chromatograms of the UPLC-MS/MS obtained under MRM operation of the TTX standard. TIC (total ion chromatogram). TTX standard $1000 \mathrm{ng} / \mathrm{mL}$, $m / z, 320>302 / 162$.

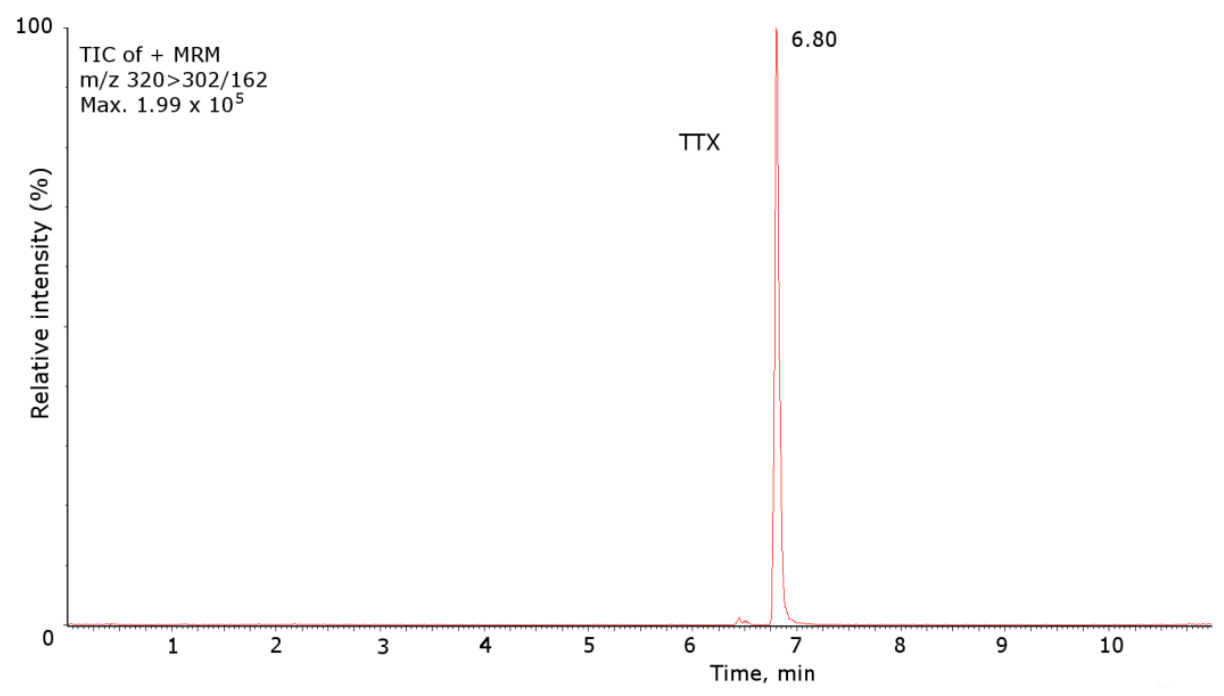

The analysis of the gastropod collected in our waters allowed us to detect some positive samples, including G. umbilicalis, collected on Memória beach in July 2009. The peaks corresponded to monodeoxyTTX, with an amount of $63.81 \mathrm{ng} / \mathrm{g}$ (Figure 4).

Two other gastropod species had positive results: M. lineata collected in April 2010 in Vila Nova de Milfontes and C. lampas collected in September 2010 in Angeiras (Figure 5). While the first revealed the co-occurrence of TTX $(90.50 \mathrm{ng} / \mathrm{g})$ and 4-epiTTX $(21.48 \mathrm{ng} / \mathrm{g})$, in C. lampas we detected low levels of 5,6,11-trideoxyTTX $(6.22 \mathrm{ng} / \mathrm{g})$. This last variant was detected previously in the same species, together with TTX [21]. Nevertheless, this is the first report on the occurrence of TTX and variants in the two small gastropods $M$. lineata and G. umbilicalis. These two species, regardless of their small size, are harvested and consumed by locals, being rarely found in markets. Thus, the exposure of TTX and analogues via these small gastropods is neither regulated nor controlled.

The levels of these toxins found in our samples are relatively low when compared to other species that had caused human intoxications, or even with the C. lampas that caused the intoxication episode in Malaga [21]. In Table 1 the toxin levels detected in the present work and examples of other works for comparison are displayed. Nevertheless, one should be careful when comparing data, since the levels we report are due to the toxin content in the whole animal (edible part), while the data on the C. lampas reported by Rodriguez et al. 2008 refers to levels in the digestive gland only [21]. 
Figure 4. Mass chromatograms of the LC-ESI-CID-MS/MS obtained under MRM operation of the positive sample of Gibbula umbilicalis for the analogue monodeoxyTTX $(\mathrm{m} / \mathrm{z}, 304>286 / 176)$. XIC extracted ions chromatogram.

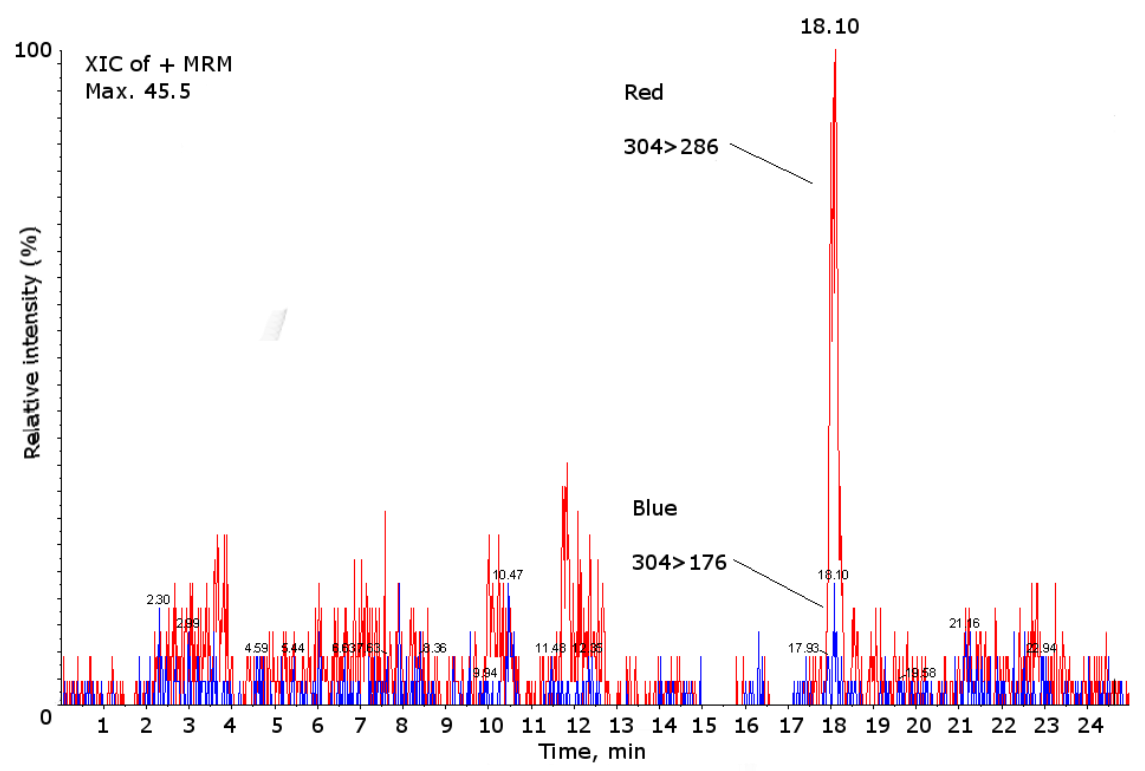

Figure 5. Mass chromatograms of the UPLC-MS/MS obtained under MRM operation of the positive samples of Monodonta lineata and C. lampas for (A): TTX ( $\mathrm{m} / z, 320>162 / 302)$, 4-epiTTX ( $\mathrm{m} / \mathrm{z}, 320>$ 162/302); and (B): 5,6,11-trideoxyTTX $(\mathrm{m} / \mathrm{z}, 272>254 / 162)$.

(A)
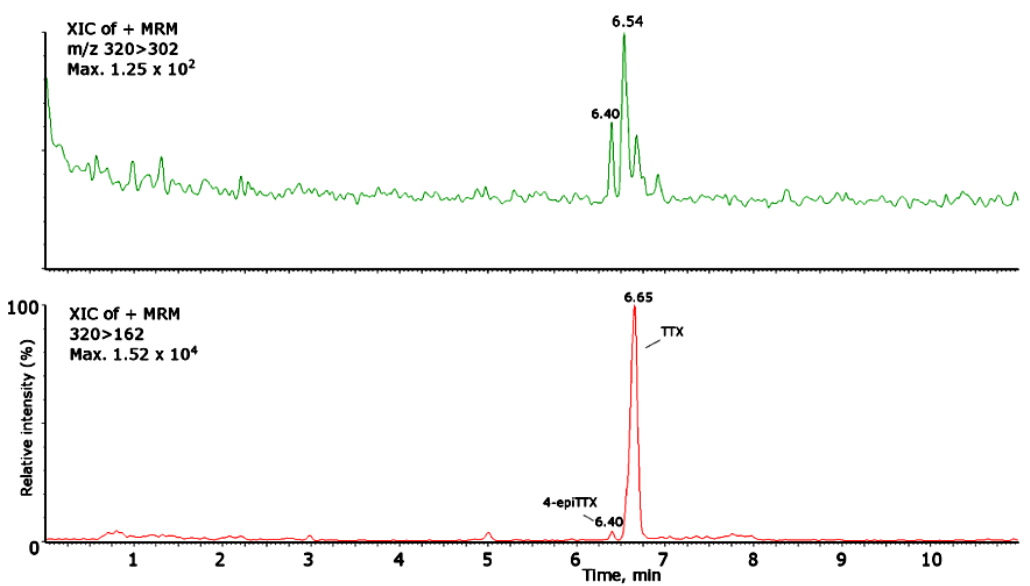

(B)
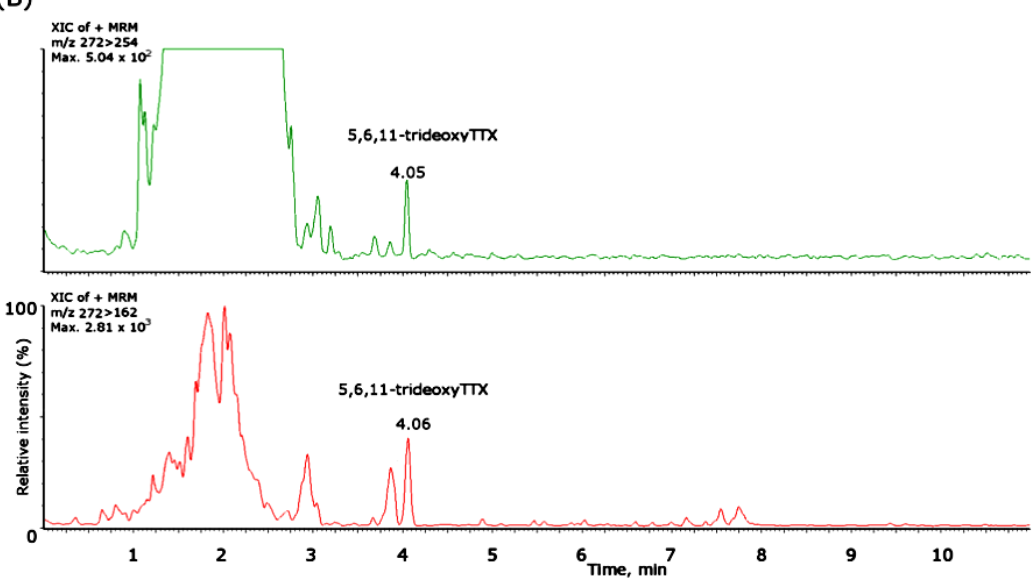
Table 1. TTX and analogues levels $(\mu \mathrm{g} / \mathrm{g})$ in marine gastropods from Portugal (pw-present work and [21]), China and Taiwan.

\begin{tabular}{llccccc}
\hline Species & Location & TTX & 4-epiTTX & MonodeoxyTTX & 5,6,11-trideoxyTTX & Ref. \\
\hline G. umbilicalis & Memória & & & 0.063 & & pw \\
M. lineata & Vila Nova de & 0.090 & 0.021 & & pw \\
& Milfontes & & & & \\
C. lampas & Angeiras & & & & 0.006 & pw \\
& Algarve & $315.00 *$ & & $1004.00 *$ & {$[21]$} \\
\hline N. nitidus & China & 1350 & & & {$[25]$} \\
N. semiplicatus & & 26.10 & 3.37 & & {$[12]$} \\
N. papillosus & Taiwan & $42-60$ & & & {$[26]$} \\
\hline \multicolumn{7}{r}{ * Data obtained from digestive gland only. }
\end{tabular}

The low levels we have found so far may also be due to the fact that TTX synthesis in warmer waters is higher than in the cold North Atlantic ones.

The "Lessepsian migration" phenomenon may play an important role in the migration of TTX-bearers to more temperate waters, such as the elongated puffer Lagocephalus sceleratus, since 1902 more than 62 Red Sea fish species have migrated via the Suez Canal to the Mediterranean [22]. Global warming may also have influenced the migration and settling of TTX-bearing species to more temperate waters, once the rise in water temperature facilitates the migration of Red Sea exotic species to the Mediterranean Sea. Since 5.7\% of the Mediterranean fauna is composed of Red Sea fish species, the risk of future invasion by these alien species is potentially very high [22]. There is not yet enough epidemiological and toxicological data concerning human intoxications by TTX in the temperate waters of the Atlantic Ocean. Nevertheless, a study done in the South Pacific area concerning the possible association of ciguatera and climate change revealed interesting assumptions that may give us some hints for future studies [27]. The study projected the idea that a rise in temperature is expected to increase the incidence of ciguatera poisoning of 35-70 per thousand people in 1990 to $160-430$ per thousand people in 2050 in Papua New Guinea [27]. Taking into account that we need to be cautious when using simplistic models such as these, the rise in temperature may alter the growth rate of the toxic organisms [28] and also the rates of toxin production [29]. Nevertheless, temperature may also alter accumulation, metabolism and detoxication kinetics in fish vectors as it can for TTX [30]. In fact, another work showed that the in vitro uptake of TTX into liver tissue slices of Takifugo rubripes is temperature dependent, being significantly higher at $20^{\circ} \mathrm{C}$ compared to $5{ }^{\circ} \mathrm{C}[30]$.

Cellular and molecular studies on the TTX kinetics are also needed in order to better predict the potential effects of global warming on TTX levels in vector species. Taking into account that the microflora of many puffer fish may be the origin of TTX, studies on the TTX production by the main bacterial species are important. A study on the diversity of bacteria isolated from the skin, gill and intestine of Fugo niphobles showed that temperature may have an effect on the diversity and density of some bacteria [31]. The identification of Vibrio sp. species, and in particular of V. alginolyticus, was achieved when fish were exposed at 20 and $29{ }^{\circ} \mathrm{C}$ but not when reared at $10{ }^{\circ} \mathrm{C}$. In laboratory culture, all strains of this species grew at 20 to $37{ }^{\circ} \mathrm{C}$ but very few grew at $10{ }^{\circ} \mathrm{C}$, suggesting a preference for higher temperatures [31]. So, water temperature may have an impact on the growth rate of TTX 
producing bacteria, being responsible for higher bacteria counts in fish exposed to higher temperatures. More laboratory experiments are needed to support this hypothesis. All these circumstances, together with the fact that TTX travels along the food-chain [5-8], may favor the establishment of TTX in Atlantic temperate waters.

In this work, TTX plus its derivatives were detected in the Portuguese coast, not only in species already reported as TTX-bearers (Charonia lampas) but also in indigenous species not yet assigned, this being the first report of TTX presence in Gibbula umbilicalis and Monodonta lineata. Apart from the quantities detected in these animals, there is an imminent danger to the human population, since the toxin travels in the food-chain and it is unknown whether or not there is biomagnification of TTX [5-8]. This increases the potential danger, because all the species reported are edible and the toxin is water soluble and thermostable [32,33].

The species Gibbula umbilicalis and Monodonta lineata belong to the same family, Trochidae [34], and in this study we confirm their ability to accumulate TTX. Possibly there is a potential adaptation that is common for both. In addition, TTX was not detected in all specimens belonging to these two species, which could be due to different strains having different capabilities of adaptation. We can make no inferences about the seasonal intake of the toxin, due to the fact that we only had three positives (2.24\% of the total sampling), although all of them were in the warmer months.

TTX is present in Portuguese waters, Angeiras being the most northern point of a TTX report in Atlantic temperate waters. Nevertheless, the low concentrations detected are not sufficient to cause a fatal outcome, since the Minimum Lethal Dose for humans is $2 \mathrm{mg}$ [35]. Surveillance is advisable to avoid poisoning incidents and to understand the progress of this emergent phenomenon.

\section{Experimental Section}

\subsection{Sampling Points and Selected Species}

TTX was reported in gastropods and sea-stars in many parts of the world [5-8,21,36-43]. Due to this fact and also because we were searching for potential new vectors, fourteen benthic species were selected, belonging to gastropods (Monodonta lineata, Monodonta turbinata, Gibbula umbilicalis, Gibbula magus, Littorina littorea, Littorina saxatilis, Nucella lapillus, Ocenebra erinacea, Calliostoma zizyphinum, Patella intermedia, Charonia lampas), bivalves (Mytilus galloprovincialis), sea-urchins (Paracentrotus lividus) and sea-stars (Marthasterias glacialis). Samples were collected monthly at various sampling sites distributed along the coast of continental Portugal (Figure 1): Almograve (37³9'11.52"N; 848'09.18"W), Vila Nova de Milfontes (3743'02.19"N; 847'34.40"W), Monte Clérigos (37²0'06.92"N; 850'48.09"W), Porto Côvo (3753'33.19"N; 847'38.25"W), São Torpes (3758'53.56"N; 847'45.58"W), São Martinho do Porto (39³0'18.29"N; 908'18.07"W), Aguda $\quad\left(41^{\circ} 02^{\prime} 52.13^{\prime \prime N} ; \quad 8^{\circ} 39^{\prime} 13.19^{\prime \prime W}\right), \quad$ Valadares $\left(41^{\circ} 5^{\prime} 29.76 " \mathrm{~N} ; \quad 8^{\circ} 39^{\prime} 27.05^{\prime \prime W}\right)$, Memória $\left(41^{\circ} 13^{\prime} 50.96^{\prime \prime N} ; \quad 8^{\circ} 43^{\prime} 18.09^{\prime \prime} \mathrm{W}\right)$, Angeiras $\left(41^{\circ} 15^{\prime} 50.01^{\prime \prime N} ; 8^{\circ} 43^{\prime} 37.14^{\prime \prime W}\right)$, Póvoa do Varzim $\left(41^{\circ} 22^{\prime} 41.61^{\prime \prime N} ; 8^{\circ} 46^{\prime} 7.39^{\prime \prime} \mathrm{W}\right)$, Esposende $\left(41^{\circ} 29^{\prime} 5.19^{\prime \prime} \mathrm{N} ; 8^{\circ} 46^{\prime} 45.76^{\prime \prime} \mathrm{W}\right)$ and Viana do Castelo $\left(41^{\circ} 41^{\prime} 35.38^{\prime \prime N} ; 8^{\circ} 50^{\prime} 56.70^{\prime \prime} \mathrm{W}\right)$. Charonia lampas were purchased at local fish markets, being caught along the Angeiras coast $\left(41^{\circ} 15^{\prime} 49.06 " \mathrm{~N} ; 8^{\circ} 43^{\prime} 48.43^{\prime \prime} \mathrm{W}\right)$. Organisms were collected in the intertidal area during low tide and were transported to the laboratory and refrigerated as soon as possible. 
Whenever they were not processed immediately, they were frozen at $-20{ }^{\circ} \mathrm{C}$. The number of samples collected and the average number of specimens needed to set a composed sample are displayed in Table 2.

Table 2. Average number of specimens to set a composed sample and number of samples collected since July 2009 until the end of 2010. Availability of animals is dependent on their geographical distribution and ecology.

\begin{tabular}{ccc}
\hline Species & $\begin{array}{c}\text { Number of Samples Collected } \\
\text { from July 2009 till End 2010 }\end{array}$ & $\begin{array}{c}\text { Average Number of Animals } \\
\text { Collected to Set a Composed } \\
\text { Sample }\end{array}$ \\
\hline Gibbula umbilicalis & 34 & 100 \\
Gibbula magus & 1 & 90 \\
Monodonta lineata & 20 & 86 \\
Monodonta turbinata & 21 & 86 \\
Nucella lapillus & 13 & 15 \\
Littorina littorea & 2 & 10 \\
Littorina saxatilis & 4 & 15 \\
Ocenebra erinacea & 4 & 4 \\
Calliostoma zizyphinum & 1 & 1 \\
Patella intermedia & 4 & 15 \\
Charonia lampas & 5 & 1 \\
Mytilus galloprovincialis & 7 & 30 \\
Paracentrotus lividus & 10 & 10 \\
Marthasterias glacialis & 8 & 1 \\
\hline
\end{tabular}

\subsection{Sample Treatment}

Due to the small size of some species, and in order to have enough biomass for the extraction procedure ( $1 \mathrm{~g})$, all animals were treated in groups with the exception of Charonia lampas, Calliostoma zizyphinum and Marthastherias glacialis. In Table 2 the number of animals needed to set a composed extractable sample is displayed. Samples were extracted based on the methods of Shoji et al. and Ito et al. with appropriate amendments to the type of sample [44,45] as follows. Gastropods were boiled in water for 30 min due to their hard consistency. All samples were dissolved in acetic acid (1\%), then homogenized with a mechanical crusher (1000 rpm, $5 \mathrm{~min}$ ), (Silentcrusher M, Heidolph, VWR, Carnaxide, Portugal), and ultrasonication (70 Hz, $3 \mathrm{~min}$ ), (Vibra Cell, Sonic \& Materials, Reagent 5, Porto, Portugal). The extracts were then centrifuged at $4495 \mathrm{~g}$ for $20 \mathrm{~min}$ (Centrifugal-Legend RT, Sorvall). This procedure was repeated twice, and the two supernatants were defatted with dichloromethane $(\mathrm{v} / \mathrm{v})$. Both layers were collected and concentrated under reduced pressure $\left(40{ }^{\circ} \mathrm{C}\right)$ in a rotary evaporator (Büchi) and stored at $-20^{\circ} \mathrm{C}$ [44-48]. This method was used in the first 50 samples, and then the extraction method was optimized in order to obtain cleaner extracts, based on the protocols of Jen et al. and Tsai et al. [49,50]: $1 \mathrm{~g}$ of sample tissue was homogenized with a blender (A320R1, $700 \mathrm{~W}$, Moulinex) then extracted in $3 \mathrm{~mL}$ of acetic acid (1\%)/methanol with the help of a vortex mixer for 5 min (Top Mix 1118, Fisher Bioblock Scientific) and ultrasonic bath, (5 min, $100 \mathrm{~Hz})(\mathrm{RK} 100 \mathrm{H}$, Bandelin SONOREX). A double extraction was performed, extracts were centrifuged at $4495 \mathrm{~g}$ for 
15 min at $4{ }^{\circ} \mathrm{C}$ (Centrifugal-Legend RT, Sorvall), supernatants were combined and adjusted to a final volume of $7 \mathrm{~mL}$. Then $1 \mathrm{~mL}$ of the extract was cleaned through a C18 solid-phase extraction (SPE) cartridge $(500 \mathrm{mg} / 3 \mathrm{~mL}$ volume from Supelco, Bellefonte, PA, USA). The cartridges were previously conditioned with $6 \mathrm{~mL}$ of methanol, followed by $6 \mathrm{~mL}$ of water (milliQ). The sample was eluted with $10 \mathrm{~mL}$ of $100 \%$ methanol and diluted with the same solvent to a final volume of $12 \mathrm{~mL}$. Finally, each sample was concentrated by drying and re-suspended in $1 \mathrm{~mL}$ of methanol, and $100 \mu \mathrm{L}$ were filtered through $0.45 \mu \mathrm{m}$ filters (UltraFree-MC centrifugal devices, Millipore, Spain) before LC-MS/MS analysis [49,50]. All reagents used were paranalysis grade from Merck ${ }^{\circledR}$.

\subsection{LC-MS/MS Analysis}

The LC-MS conditions were the same as reported by Rodriguez et al. [24]. Briefly, the analyses were performed in high-performance liquid chromatography (LC) equipment consisting of a binary system of LC-10ADVP pumps, an autoinjector (SIL-10ADVP) with degasser (DGU-14A), refrigerated rack, column oven (CTO-10ACvp) and a system controller (SCL-10Avp) from Shimadzu (Kyoto, Japan). The LC system was coupled to a 2000 QTRAPLC/MS/MS instrument from Applied Biosystems (Calrsbad, CA, USA), formed by a hybrid quadrupole-linear ion trap mass spectrometer (MS), equipped with an atmospheric pressured ionisation (API) unit, fitted with an electrospray ionisation source (ESI), operating in the conventional mode of low energy of collision dissociation induced (CID) of MS/MS. Nitrogen was produced by a Nitrocraft $\mathrm{NC}_{\mathrm{LC} / \mathrm{MS}}$ generator from Air Liquide (Madrid, Spain).

The LC system operated with the ESI interface in positive ion mode using the following parameters: curtain gas, 15 psi; collision-activated dissociation gas, 6 psi; IonSpray voltage, $4000 \mathrm{~V}$; temperature, $450{ }^{\circ} \mathrm{C}$; gas $1,50 \mathrm{psi}$; gas $2,50 \mathrm{psi}$; these parameters had been previously optimized using the TTX standard (Calbiochem Corporation). For the equipment control, data processing and analysis, Analyst software was used. Eluent (A) of the mobile phase was composed by formic acid (Merck, Madrid, Spain) and ammonium formate (Sigma Aldrich, Madrid, Spain), both with a concentration of $10 \mathrm{mM}$ in water, and eluent (B) consisted of acetonitrile (Panreac Quimica, Barcelona, Spain) in water (95:5) with ammonium formate $(5 \mathrm{mM})$ and formic acid $(2 \mathrm{mM})$. The gradient used started with $100 \%$ of mobile phase (B), decreasing to $65 \%$ at minute 15 , rising to $100 \%$ at minute 18 until the end of the run (25 min). An XBridge ${ }^{\mathrm{TM}}$ Amide column (i.d. $2.1 \times 150 \mathrm{~mm} ; 3.5 \mu \mathrm{m}$ ) with a guard cartridge (i.d. $2.1 \times 10 \mathrm{~mm}$ ) from Waters (Cerdanyola del Vallès, Spain) was used to achieve the separation of TTX, and analogues present in the samples. Column oven temperature was set at $25{ }^{\circ} \mathrm{C}$ and injection volume was $5 \mu \mathrm{L}$. The MS was operated in multiple reactions monitoring (MRM) mode, analysing two product ions per compound: one for quantification and the other for confirmation.

The mass spectrometer parameters were adjusted to obtain a signal of maximum intensity and stability. For the MS optimization, the sample solution was directly infused in the electrospray source at a $0.2 \mathrm{~mL} / \mathrm{min}$ flow rate with a syringe pump. The MS was operated in the positive ion mode using the product ion scan with a cone gas, $40 \mathrm{~V}$; capillary voltage, $2.8 \mathrm{kV}$; source temperature, $120{ }^{\circ} \mathrm{C}$; desolvation temperature, $350{ }^{\circ} \mathrm{C}$; collision energy, $45 \mathrm{eV}$. Helium and nitrogen were used as collision and drying gases, respectively [24].

To overcome the challenge of the lack of standards for TTX analogues [44,51-55] a sample of a naturally-contaminated Charonia lampas and Lagocephalus sceleratus used in former works [21,24] 
was injected in the LC-MS/MS, this way determining the respective retention times (RT) (Figure 2). The following variants were aimed for: TTX, 4-epiTTX, 5,6,11-trideoxyTTX, monodeoxyTTX, 11-norTTX-6-ol and 4-anhydroTTX. For the calibration curve, several dilutions from the TTX standard were performed, from $50 \mathrm{ng} / \mathrm{mL}$ concentration to $2000 \mathrm{ng} / \mathrm{mL}$. TTX and its derivatives were quantified, using their peak areas to calculate amounts and using the curve obtained from TTX standard [56].

\subsection{UPLC-MS/MS Analysis}

Samples were analysed in Ultra High Performance Liquid Chromatography equipment ACQUITY UPLC system, coupled to a Xevo TQ MS mass spectrometer from Waters (Manchester, UK). The apparatus is equipped with a multimode source ESI/APCI/ESCi, a vacuum system composed of two air-cooled Edwards Vacuum turbo molecular pumps evacuating the source and analyzer, one Varian rotary backing pump. The nitrogen generator was a Nitrocraft $\mathrm{NC}_{\mathrm{LC} / \mathrm{MS}}$ from Air Liquide (Madrid, Spain). Chromatographic separation and detection of TTX and its derivatives was achieved with a Waters Acquity UPLC BEH Amide column $(100 \mathrm{~mm} \times 2.1,1.7 \mu \mathrm{m})$, equipped with a $0.2 \mu \mathrm{m}$ Acquity UPLC in-line filter and column oven at $35^{\circ} \mathrm{C}$. The LC operated with eluent (A), consisting of $10 \mathrm{mM}$ ammonium formate (Sigma Aldrich, Madrid, Spain) and $10 \mathrm{mM}$ formic acid (Merck, Madrid, Spain) in water. Eluent (B) contained acetonitrile (Panreac Quimica, Barcelona, Spain) in water (95:5) with a final concentration of $5 \mathrm{mM}$ ammonium formate and $2 \mathrm{mM}$ formic acid. The gradient programme used to elute the toxins was $100 \%$ mobile phase (B) at the beginning, decreasing to $65 \%$ (B) after $7 \mathrm{~min}$, then kept for 2 min and back to 100\% (B) over the next 0.5 min and finally kept $100 \%$ (B) for $1.5 \mathrm{~min}$ before the next injection. Flow rate was $0.4 \mathrm{~mL} / \mathrm{min}$ and injection volume was $5 \mu \mathrm{L}$.

The Xevo TQ MS mass spectrometer operated with the following optimized source-dependent parameters (ESI source): capillary potential $2.7 \mathrm{kV}$, cone voltage $40 \mathrm{~V}$, desolvation temperature $350{ }^{\circ} \mathrm{C}$, desolvation gas flow $850 \mathrm{~L} / \mathrm{h} \mathrm{N} \mathrm{N}_{2}$, cone gas flow $50 \mathrm{~L} / \mathrm{h} \mathrm{N} \mathrm{N}_{2}$, source temperature $150{ }^{\circ} \mathrm{C}$, collision gas flow $20 \mathrm{~V}$. Argon was used as the collision gas at $4.5 \times 10^{-3} \mathrm{mbar}$.

The mass spectrometer operated in MRM, detecting in positive mode, analysing two product ions per compound: one for quantification and another for confirmation. The transitions employed were: TTX and 4-epiTTX (m/z $320>302 / 162)$ and 5,6,11-trideoxyTTX $(272>254 / 162)$, with retention times: TTX (6,80 $\mathrm{min})$, 4-epiTTX (6.50 $\mathrm{min}$ ) and 5,6,11-trideoxyTTX (4.06 min). Quantification was undertaken with the most abundant ion in the fragment spectra: 162 for TTX, 4-epiTTX and 5,6,11-trideoxyTTX. TTX analogues in sample solutions were identified according to the daughter ion spectra of the analogues reported in the literature [44]. For the calibration curve, several dilutions from the TTX standard (Calbiochem Corporation) were performed, from $31.25 \mathrm{ng} / \mathrm{mL}$ concentration to $3000 \mathrm{ng} / \mathrm{mL}$. TTX and its derivatives were quantified using their peak areas to calculate amounts and using the curve obtained from TTX standard [56].

\section{Conclusions}

In this work we used LC-MS/MS and UPLC-MS/MS to detect TTX and several analogues in three autochthonous gastropod species of the Atlantic Portuguese continental coast. TTX, 4-epiTTX, monodeoxyTTX and 5,6,11-trideoxyTTX were detected in Monodonta lineata, Gibbula umbilicalis 
and Charonia lampas, being the most northern point of the Atlantic Ocean were these toxins were reported. All these species are edible, raising the probability of human health hazards. Despite the low concentrations detected, ranging from 6.22 to $90.50 \mathrm{ng} / \mathrm{g}$, it was clearly shown that TTX and analogues should be monitored in the species reported positive, and in others that can potentially accumulate the toxins and can be used as human food.

\section{Acknowledgments}

We acknowledge the INTERREG IV projects Atlantox and Pharmatlantic for partially funding this research, UP through IJUP projects and Ministerio de Ciencia y Tecnología, Spain: AGL2009-13581-C02-01. MS acknowledges FCT (SFRH/BD/73269/2010).

\section{References}

1. Tahara, Y.; Hirata, Y. Studies on the puffer fish toxin. J. Pharm. Soc. Jpn. 1909, 29, 587-625.

2. Miyazawa, K.; Noguchi, T. Distribution and origin of tetrodotoxin. J. Toxicol. Toxin Rev. 2001, 20,11-33.

3. Matsumura, K. Production of tetrodotoxin in puffer fish embryos. Environ. Toxicol. Pharmacol. 1998, 6, 217-219.

4. Lehman, E.M.; Brodie, E.D.; Brodie, E.D. No evidence for an endosymbiotic bacterial origin of tetrodotoxin in the newt Taricha granulosa. Toxicon 2004, 44, 243-249.

5. Lin, S.J.; Hwang, D.F. Possible source of tetrodotoxin in the starfish Astropecten scoparius. Toxicon 2001, 39, 573-579.

6. Yasumoto, T.; Yotsu-Yamashita, M. Chemical and etiological studies on tetrodotoxin and its analogs. J. Toxicol. Toxin Rev. 1996, 15, 81-90.

7. Kono, M.; Matsui, T.; Furukawa, K.; Yotsu-Yamashita, M.; Yamamori, K. Accumulation of tetrodotoxin and 4,9-anhydrotetrodotoxin in cultured juvenile kusafugu Fugu niphobles by dietary administration of natural toxic komonfugu Fugu poecilonotus liver. Toxicon 2008, 51, 1269-1273.

8. Noguchi, T.; Arakawa, O.; Takatani, T. Toxicity of pufferfish Takifugu rubripes cultured in netcages at sea or aquaria on land. Comp. Biochem. Physiol. Part D: Genomics Proteomics 2006, 1, 153-157.

9. Hwang, D.F.; Arakawa, O.; Saito, T.; Noguchi, T.; Simidu, U.; Tsukamoto, K.; Shida, Y.; Hashimoto, K. Tetrodotoxin-producing bacteria from the blue-ringed octopus Octopus maculosus. Mar. Biol. 1989, 100, 327-332.

10. Noguchi, T.; Hwang, D.F.; Arakawa, O.; Sugita, H.; Deguchi, Y.; Shida, Y.; Hashimoto, K. Vibrio alginolyticus, a tetrodotoxin-producing bacterium, in the intestines of the fish Fugu vermicularis vermicularis. Mar. Biol. 1987, 94, 625-630.

11. Yotsu, M.; Yamazaki, T.; Meguro, Y.; Endo, A.; Murata, M.; Naoki, H.; Yasumoto, T. Production of tetrodotoxin and its derivatives by Pseudomonas sp. isolated from the skin of a pufferfish. Toxicon 1987, 25, 225-228.

12. Wang, X.J.; Yu, R.C.; Luo, X.; Zhou, M.J.; Lin, X.T. Toxin-screening and identification of bacteria isolated from highly toxic marine gastropod Nassarius semiplicatus. Toxicon 2008, 52, 55-61.

13. Cestele, S.; Catterall, W.A. Molecular mechanisms of neurotoxin action on voltage-gated sodium channels. Biochimie 2000, 82, 883-892. 
14. Choudhary, G.; Yotsu-Yamashita, M.; Shang, L.; Yasumoto, T.; Dudley, S.C., Jr. Interactions of the C-11 hydroxyl of tetrodotoxin with the sodium channel outer vestibule. Biophys. J. 2003, 84, 287-294.

15. Hille, B. The receptor for tetrodotoxin and saxitoxin: A structural hypothesis. Biophys. J. 1975, 15, 615-619.

16. Scheib, H.; McLay, I.; Guex, N.; Clare, J.; Blaney, F.; Dale, T.; Tate, S.; Robertson, G. Modeling the pore structure of voltage-gated sodium channels in closed, open, and fast-inactivated conformation reveals details of site 1 toxin and local anesthetic binding. J. Mol. Model. 2006, 12, 813-822.

17. Kaku, N.; Meier, J. Clinical Toxicology of Fugu Poisoning. In Handbook of Clinical Toxicology of Animal Venoms and Poisons; Meier, J., White, J., Eds.; CRC Press: Boca Raton, FL, USA, 1995; pp. 75-83.

18. Bentur, Y.; Ashkar, J.; Lurie, Y.; Levy, Y.; Azzam, Z.S.; Litmanovich, M.; Golik, M.; Gurevych, B.; Golani, D.; Eisenman, A. Lessepsian migration and tetrodotoxin poisoning due to Lagocephalus sceleratus in the eastern Mediterranean. Toxicon 2008, 52, 964-968.

19. Katikou, P.; Georgantelis, D.; Sinouris, N.; Petsi, A.; Fotaras, T. First report on toxicity assessment of the Lessepsian migrant pufferfish Lagocephalus sceleratus (Gmelin, 1789) from European waters (Aegean Sea, Greece). Toxicon 2009, 54, 50-55.

20. Zaki, M.A.; Mossa, A.E.W. Red Sea puffer fish poisoning: Emergency diagnosis and management of human intoxication. Egypt. J. Aquat. Res. 2005, 31, 370-378.

21. Rodriguez, P.; Alfonso, A.; Vale, C.; Alfonso, C.; Vale, P.; Tellez, A.; Botana, L.M. First toxicity report of tetrodotoxin and 5,6,11-trideoxyTTX in the trumpet shell Charonia lampas lampas in Europe. Anal. Chem. 2008, 80, 5622-5629.

22. Lasram, F.B.; Mouillot, D. Increasing southern invasion enhances congruence between endemic and exotic Mediterranean fish fauna. Biol. Invasions 2009, 11, 697-711.

23. Akyol, O.; Unal, V.; Ceyhan, T.; Bilecenoglu, M. First confirmed record of Lagocephalus sceleratus (Gmelin, 1789) in the Mediterranean Sea. J. Fish Biol. 2005, 66, 1183-1186.

24. Rodriguez, P.; Alfonso, A.; Otero, P.; Katikou, P.; Georgantelis, D.; Botana, L.M. Liquid chromatography-mass spectometry method to detect tetrodotoxin and its analogues in puffer fish Lagocephalus sceleratus (Gmelin, 1789) from European waters. Food Chem. 2012, 132, 1103-1111.

25. Huang, H.N.; Lin, J.; Lin, H.L. Identification and quantification of tetrodotoxin in the marine gastropod Nassarius by LC-MS. Toxicon 2008, 51, 774-779.

26. Jen, H.C.; Lin, S.J.; Lin, S.Y.; Huang, Y.W.; Liao, I.C.; Arakawa, O.; Hwang, D.F. Occurrence of tetrodotoxin and paralytic shellfish poisons ina gastropod implicated in food poisoning in southern Taiwan. Food Addit. Contam. 2007, 24, 902-909.

27. Llewellyn, L.E. Revisiting the association between sea surface temperature and the epidemiology of fish poisoning in the south Pacific: Reassessing the link between ciguatera and climate change. Toxicon 2010, 56, 691-697.

28. Chinain, M.; Germain, M.; Deparis, X.; Pauillac, S.; Legrand, A.M. Seasonal abundance and toxicity of the dinoflagellate Gambierdiscus spp. (Dinophyceae), the causative agent of ciguatera in Tahiti, French Polynesia. Mar. Biol. 1999, 135, 259-267. 
29. Ashton, M.; Tosteson, T.; Tosteson, C. The effect of elevated temperature on the toxicity of the laboratory cultured dinoflagellate Ostreopsis lenticularis (Dinophyceae). Rev. Biol. Trop. 2003, 51, 1-6.

30. Matsumoto, T.; Nagashima, Y.; Kusuhara, H.; Sugiyama, Y.; Ishizaki, S.; Shimakura, K.; Shiomi, K. Involvement of carrier-mediated transport system in uptake of tetrodotoxin into liver tissue slices of puffer fish Takifugu rubripes. Toxicon 2007, 50, 173-179.

31. Sugita, H.; Iwata, J.; Miyajima, C.; Kubo, T.; Noguchi, T.; Hashimoto, K.; Deguchi, Y. Changes in microflora of a puffer fish Fugu niphobles, with different water temperatures. Mar. Biol. 1989, 101, 299-304.

32. Kao, C.Y. Structure-activity relations of tetrodotoxin, saxitoxin and analogues. Ann. N.Y. Acad. Sci. 1986, 479, 52-67.

33. Hommel, D.; Hulin, A.; Saignavong, S.; Desbordes, J.M. Intoxication par poisson-coffre (tetrodotoxine). A propos d'une intoxication familiale. Méd. Afr. Noire 1992, 39, 146-148.

34. Bouchet, P.; Rocroi, J.-P. Classification and nomenclator of gastropod families. Malacologia 2005, 47, 1-397.

35. Noguchi, T.; Ebesu, J.S.M. Puffer poisoning: Epidemiology and treatment. J. Toxicol. Toxin Rev. 2001, 20, 1-10.

36. Hwang, D.F.; Lu, S.C.; Jeng, S.S. Occurrence of tetrodotoxin in the gastropods Rapana rapiformis and $R$. venosa venosa. Mar. Biol. 1991, 111, 65-69.

37. Hwang, P.A.; Tsai, Y.H.; Deng, J.F.; Cheng, C.A.; Ho, P.H.; Hwang, D.F. Identification of tetrodotoxin in a marine gastropod (Nassarius glans) responsible for human morbidity and mortality in Taiwan. J. Food Protect. 2005, 68, 1696-1701.

38. Maruyama, J.; Noguchi, T.; Narita, H.; Nara, M.; Jeon, J.K.; Otsuka, M.; Hashimoto, K. Occurrence of tetrodotoxin in a starfish, Astropecten scoparius. Agric. Biol. Chem. Tokyo 1985, 49, 3069-3070.

39. Narita, H.; Noguchi, T.; Maruyama, J.; Nara, M.; Hashimoto, K. Occurrence of a tetrodotoxin-associated substance in a gastropod, Hanamushirogai Zeuxis siquijorensis. Bull. Jpn. Soc. Sci. Fish. 1984, 50, 85-88.

40. Noguchi, T.; Narita, H.; Maruyama, J.; Hashimoto, K. Tetrodotoxin in the starfish Astropecten polyacanthus, in association with toxification of a trumpet shell, Boshubora Charonia sauliae. Bull. Japan. Soc. Sci. Fish. 1982, 48, 1173-1177.

41. Hwang, P.A.; Tsai, Y.H.; Lu, Y.H.; Hwang, D.F. Paralytic toxins in three new gastropod (Olividae) species implicated in food poisoning in southern Taiwan. Toxicon 2003, 41, 529-533.

42. Narita, H.; Noguchi, T.; Maruyama, J.; Ueda, Y.; Hashimoto, K.; Watanabe, Y.; Hida, K. Occurrence of tetrodotoxin in a trumpet shell, Boshubora Charonia sauliae. Bull. Jpn. Soc. Sci. Fish. 1981, 47, 935-941.

43. Noguchi, T.; Maruyama, J.; Ueda, Y.; Hashimoto, K.; Harada, T. Occurrence of tetrodotoxin in the japanese ivory shell Babylonia japonica. Bull. Jpn. Soc. Sci. Fish. 1981, 47, 909-914.

44. Shoji, Y.; Yotsu-Yamashita, M.; Miyazawa, T.; Yasumoto, T. Electrospray ionization mass spectrometry of tetrodotoxin and its analogs: Liquid chromatography/mass spectrometry, tandem mass spectrometry, and liquid chromatography/tandem mass spectrometry. Anal. Biochem. 2001, $290,10-17$. 
45. Ito, K.; Okabe, S.; Asakawa, M.; Bessho, K.; Taniyama, S.; Shida, Y.; Ohtsuka, S. Detection of tetrodotoxin (TTX) from two copepods infecting the grass puffer Takifugu niphobles: TTX attracting the parasites? Toxicon 2006, 48, 620-626.

46. Lee, M.J.; Jeong, D.Y.; Kim, W.S.; Kim, H.D.; Kim, C.H.; Park, W.W.; Park, Y.H.; Kim, K.S.; Kim, H.M.; Kim, D.S. A tetrodotoxin-producing Vibrio strain, LM-1, from the puffer fish Fugo vermicularis radiatus. Appl. Environ. Microbiol. 2000, 66, 1698-1701.

47. Mahmud, Y.; Yamamori, K.; Noguchi, T. Occurence of TTX in a brackish water puffer "Midorifugu", Tetraodon nigroviridis, collected from Thailand. J. Food Hyg. Soc. Jpn. 1999, 40, 363-367.

48. Maruyama, J.; Noguchi, T.; Jeon, J.K.; Harada, T.; Hashimoto, K. Occurrence of tetrodotoxin in the starfish Astropecten latespinosus. Experientia 1984, 40, 1395-1396.

49. Jen, H.C.; Lin, S.J.; Tsai, Y.H.; Chen, C.H.; Lin, Z.C.; Hwang, D.F. Tetrodotoxin poisoning evidenced by solid-phase extraction combining with liquid chromatography-tandem mass spectrometry. J. Chromatogr. B: Anal. Technol. Biomed. Life Sci. 2008, 871, 95-100.

50. Tsai, Y.H.; Ho, P.H.; Hwang, C.C.; Hwang, P.A.; Cheng, C.A.; Hwang, D.F. Tetrodotoxin in several species of xanthid crabs in southern Taiwan. Food Chem. 2006, 95, 205-212.

51. Yotsu-Yamashita, M. Chemistry of puffer fish toxin. J. Toxicol. Toxin Rev. 2001, 20, 51-66.

52. Jang, J.H.; Lee, J.S.; Yotsu-Yamashita, M. LC/MS analysis of tetrodotoxin and its deoxy analogs in the marine puffer fish Fugu niphobles from the southern coast of Korea, and in the brackishwater puffer fishes Tetraodon nigroviridis and Tetraodon biocellatus from southeast Asia. Mar. Drugs 2010, 8, 1049-1058.

53. Diener, M.; Christian, B.; Ahmed, M.S.; Luckas, B. Determination of tetrodotoxin and its analogs in the puffer fish Takifugu oblongus from Bangladesh by hydrophilic interaction chromatography and mass-spectrometric detection. Anal. Bioanal. Chem. 2007, 389, 1997-2002.

54. Pires, O.R.; Sebben, A.; Schwartz, E.F.; Bloch, C.; Morales, R.A.V.; Schwartz, C.A. The occurrence of 11-oxotetrodotoxin, a rare tetrodotoxin analogue, in the brachycephalidae frog Brachycephalus ephippium. Toxicon 2003, 42, 563-566.

55. Nakagawa, T.; Jang, J.; Yotsu-Yamashita, M. Hydrophilic interaction liquid chromatography-electrospray ionization mass spectrometry of tetrodotoxin and its analogs. Anal. Biochem. 2006, 352, 142-144.

56. Yotsu-Yamashita, M.; Jang, J.H.; Cho, Y.K.; Konoki, K. Optimization of simultaneous analysis of tetrodotoxin, 4-epitetrodotoxin, 4,9-anhydrotetrodotoxin, and 5,6,11-trideoxytetrodotoxin by hydrophilic interaction liquid chromatography-tandem mass spectrometry. Forensic Toxicol. 2011, 29, 61-64.

Samples Availability: Available from the authors.

(C) 2012 by the authors; licensee MDPI, Basel, Switzerland. This article is an open access article distributed under the terms and conditions of the Creative Commons Attribution license (http://creativecommons.org/licenses/by/3.0/). 